\title{
AFRIKA GAZDASÁGA A KULTURÁLIS ANTROPOLÓGIA SZEMSZÖGÉBŐL
}

\section{AFRICA'S ECONOMY FROM THE PERSPECTIVE OF CULTURAL ANTHROPOLOGY}

\author{
Biernaczky Szilárd \\ kandidátus, ny. egyetemi docens \\ az AHU Magyar Afrika-Tudás Tár felelős szerkesztője \\ bierszilard@gmail.com
}

\begin{abstract}
ÖSSZEFOGLALÁS
Ha Afrika gazdaságát kulturális, társadalmi és legfőképpen gazdasági antropológiai oldaláról is vizsgáljuk, kiderül, hogy a globális közelítésmód számos területen és vonatkozásban tévútra vezet(het). Hiszen az egész kontinensre kitekintő nemzetközi statisztikákban nem szerepelnek az önellátásából adódó jövedelmek kevéssé számszerűsíthető adatai. Másrészt nem követhetők nyomon az egyes országok, még inkább az egyes etnikumok között adódó jelentős különbségek. Nem érzékelhetőek a helyi háborúk gazdasági következményei sem. Sőt az sem, hogy az egyes etnikumok között emberi adottságai folytán mekkora különbségek adódnak produkciós képességeiket illetően. A tanulmány példák sorával igyekszik alátámasztani e kérdésfeltevések valóságtartalmát, és szorgalmazni Afrika gazdaságának vizsgálatát e másféle megközelítés alapján.
\end{abstract}

\section{ABSTRACT}

If we examine the economy of Africa from the point of view of cultural, social and, above all, economic anthropology, it turns out that the global approach leads (or can lead) to misconceptions in many areas and aspects. As international statistics on the whole continent do not include the low quantifiable data on self-sufficiency. On the other hand, significant differences between countries, even more so among ethnicities, are not monitored in statistics covering the entire continent. Even, the economic consequences of local wars are not perceptible. What is more, the differences in the production capabilities of individual ethnicities are due to their human capabilities. The study attempts to corroborate the factuality of these questions with a series of examples, and to encourage an examination of Africa's economy on the basis of this other approach.

Kulcsszavak: Afrika gazdasága, kulturális antropológia, a szubszaharai Afrika valósága, globalitás és lokális sajátosságok, önellátás, helyi piacok, hagyományos törzsi kultúrák és társadalmak

Keywords: Africa's economy, cultural anthropology, reality of Sub-Saharan Africa, globality and local specialities, self-sufficiency, local markets, traditional tribal cultures and societies 
Úgy vélem, sokunk tapasztalata az, hogy miközben nemcsak a világ maga, hanem a különféle szakterületeken zajló tudományos kutatás is mintegy globalizálódik, ugyanakkor számos esetben találjuk szemben magunkat azzal a helyzettel, hogy valamely problémakör már csak interdiszciplináris megközelítéssel volna megoldható. Ez azonban valahogy mégis elmarad.

Meggyőződésem, hogy például szemrevételezve a mai Afrika gazdasági állapotát, e helyzettel könnyedén szembesülhetünk, mivel a nyelvi-kulturális és társadalmi fejlődés oly sokféle régebbi, sőt, régi állapotát felmutató jelenséggel találkozhatunk itt, hogy azok a kontinens méretü (tehát globális!) mutatókat és az ezekre alapozott elemzéseket sok szempontból és sok vonatkozásban bizonytalanná teszik, adott esetben akár megtévesztő eredményeket sugallnak (lásd később a szegénységi küszöb alatt élők kérdését).

Jól nyomon követhető mindaz, amire bevezető mondatainkkal igyekeztünk rávilágítani, többek között akár annak a nemrégiben megjelent, két kitűnő magyar közgazdász szerkesztetésében és magyar szerzők tollából született írásokból öszszeállított monográfiának az alapján is, amely lényegében az afrikai gazdasági élet minden lényeges kérdéskörét érinti, mégpedig természetesen a legkorszerübb ismeretek birtokában (Biedermann-Kiss, 2017). Így Szentes Tamás akadémikus már az első fejezetben szembesít bennünket a legfőbb tényekkel és a különféle gazdaságelméleti közelítésmódokkal. A kötet többi szerzője pedig a jelenlegi legaktuálisabb adatok, felmérések, jelentések és áttekintések birtokában igyekszik, egyrészt helyzetképet adni, másrészt sokrétü elemzésekkel az összefüggéseket feltárni.

Jelen kutató mindemellett nem ennek az adott kötetnek az ismertetését és méltatását kívánja elvégezni - lévén hogy nem a közgazdaság-tudomány, hanem a néprajz, etnológia, illetve kulturális antropológia a szakmája -, hanem arra a gondolatra jutott, hogy érdemes volna a gazdasági antropológia egyes alapvető tényeivel is szembesíteni az érdeklődő olvasót. Vagyis ráébredt arra, hogy e tudományterületen csak akkor juthat szóhoz, ha a világszerte előtérbe került és az említett kötetben is feldolgozott témakörök kapcsán sorra veszi, melyek azok a tények, amelyek az ugyancsak világszerte és így ebben a kötetben is érvényesülő globális szemléletmód hatására lényegében elsikkadtak, vagy egyszerüen kimaradtak.

\section{VALÓS NÉPESSÉGSZÁM - SZEGÉNYSÉG - HELYI GAZDASÁG}

Így a demográfiai trendekkel kapcsolatos mutatók, illetve a népességnövekedési folyamatok kapcsán, még ha azok a legfrissebb adatbázisokon és tényfeltárásokon alapulnak is, azt kell látnunk, hogy sehol sem merül fel a hiányzó vagy az újabb, illetve sok esetben csak régről létező népszámlálásokból származó 
pontatlanságok kérdése, másrészt azoknak az élethelyzeteknek a vetülete, amelyek éppen a hagyományos társadalmi helyzetből vagy egyszerüen valamely speciális földrajzi körülményből adódnak, a helyi mindennapi gyakorlat következményei.

Annak idején a nyolcvanas években a shilluk (Dél-Szudán) származású Joseph Bol Chan, Magyarországon tanuló történész-újságíró arról informált, miképpen zajlott annak idején náluk otthon a népszámlálás. Elmondása szerint arra jött az esős évszak idején egy csónak, és a népszámláló bekiabált hozzájuk: „Hányan vagytok?” A válasz a valós számnál jóval kevesebbről szólt, hiszen a létszám összefüggött az adózás nagyságrendjével. Vagyis ilyen és ehhez hasonló helyzetek folytán (különösen például az etnikai villongásokkal tarkított, politikailag rendezetlen országok esetében) a demográfiai adatok pontossága erősen megkérdőjelezhető. Legjobb esetben erősen hozzávetőleges eredményeket adhatnak csak.

Hasonló kulturális antropológiai repedéseket vélünk felfedezni a szegénység és egyenlőtlenség, illetve egészségügy kérdéskörét tekintve. Az első és meghatározó benyomásunk óhatatlanul abból következik, hogy léteznek afrikai számok egy före jutó hihetetlenül alacsony (napi 1 dollárnál kisebb) jövedelemről, a mélynél is mélyebb szegénység szubszaharai méreteiről. Másrészt arról, hogy orvosi ellátottság, kórházak csak nyomokban léteznek e hatalmas és majd milliárd emberrel lakott területen. Szinte úgy tünik az adatokat látva, mintha egészségügy egyáltalán nem létezne e földrészen.

Ugyanakkor szembe kellene néznünk azzal a ténnyel, hogy a Szaharától délre eső területeken élő népek, amelyeknek minden bizonnyal jóval több mint a fele nem városokban él, hanem szétszórtan, nagy területeken, a túlélésüket azzal biztosítják, hogy önellátásra rendezkedtek be. Ennek a kontinens méretủ gazdasági áttekintéseket illetően két következménye van. (1) Ez a kizárólag helyi vonatkozású önellátás (akár mezőgazdasági, akár állattartási tevékenységgel párosul) megakadályozza az éhenhalást, még ha többnyire nem is biztosít túl nagy bőséget. (2) Másrészt viszont e tevékenységek adatai vagy sehogy, vagy esetleg csak becsléssel kerül(het)nek be a globális mutatók körébe. És így a szegénységi küszöb(ök) felvetése, mutatózása már önmagában is bizonytalanabbá válik.

Külön figyelmet igényel e tekintetben a nomadizáló állattartás, amelyet ugyan évtizedek óta próbálnak (külső segítséggel is) visszaszorítani, azonban nem sok sikerrel. Jóllehet a nagy területeket bejáró és állatok legeltetésével járó életforma problémák sorát rejti magában. (1) Az állatok tartása különleges táplálkozási formákkal jár együtt (ismeretes, hogy például a maszájok a marhák nyaki veröerét megcsapolva vérrel kevert tejet isznak, más népek nem fejik meg a teheneket, ugyancsak más népek meg nem a húsáért tartják az állatokat, azokat csak rendkívüli ünnepek alkalmával fogyasztják el). (2) Az állatokat nem táplálkozás céljára tartják (díszállatok vagy csereérték, például feleségvásárlásnál). 
(3) Az állatok néha igen nagy távolságot átfogó nomadizáló legeltetése (például az észak-szudáni arab népességek átjárnak akár Dél-Szudánba is a megfelelően zöldellő legelők nyomában) rendkívüli etnikai konfliktusokhoz vezethet (lásd az észak-szudáni arabok és a dél-szudáni fekete népesség, nuerek és dinkák hasonló legelők nyomába eredő nomadizálását, és ennek nyomában az összeütközéseket). (4) Az már csak hab a tortán, hogy ma is számos helyen előfordul, hogy egyes állattartó etnikumokból kiválik egy férficsapat a száraz időszak idején, és marharablásra indul.

Van az afrikai életnek még egy olyan jelenségköre, amely - egyszerủen a földrajzi és a gazdasági élet fóvonalától való távoli elhelyezkedése folytán - kimarad. És ez a helyi piacok problematikája. Legutóbb egy egészen más témakörben dolgozó fiatal magyar terepmunkás (Szilasi Ildikó) hozott információkat a nagy Kongóból, amelyek szerint még ma is érvényes az a helyzet, hogy a termelvények, áruk nem piacra, hanem csak saját felhasználásra készülnek. Vagy ha az adott családi közösség a saját igényeinél többet állít elő valamiből, az közvetlen csere útján talál gazdát (piacmentesen, esetleg közeli szomszédok útján). Piacra vinni valamit - ehhez helyszín szükséges.

A Paul Bohannan szerkesztésével fémjelzett egykori nagy terjedelmü és igen gazdag anyagú konferenciakötet (1962), amely máig érvényes adatokkal, leírásokkal szolgál, fényesen igazolja az említett terepmunkásunk töredékes információit. A piacok többnyire egyes kiemelt jelentőségü települések közösségi terén jönnek létre. Ezek a helyek a közösségi élet színterei is, ahová nemcsak az eladás vagy vásárlás céljából érkeznek emberek (személyes találkozások, ünnepi szokások, rítusok sora, házasságkötések stb. is zajlanak itt). Ugyanakkor e piacok müködésének néha objektív földrajzi határai vannak: például a Kongó és mellékfolyói meddig, milyen szakaszokon hajózhatók, illetve van-e a dzsungelben áthatolható terület, kitaposott út.

\section{AZ EGÉSZSÉGÜGY HELYZETE - NYERSANYAGOK - JÁRADÉKVADÁSZAT}

Ami viszont az orvoslás helyzetét illeti, nyilvánvalóan első látásra elképesztőnek tünik a szubszaharai Afrika helyzete. Minderröl ugyanakkor egészen más oldalról is vannak igen erőteljes benyomásaink, hiszen éppen nemrégiben jelent meg Pusztai Gabriella monográfiája (2016), amely egyrészt jól érzékelteti (globális mutatók híján is) az afrikai egészségügy helyzetét, egyszerủen a magyar orvosoknak a kontinensen végzett munkája bemutatásával. Ennek a könyvnek ugyanakkor az a nagy értéke, hogy a bevezetö fejezete mellett szövege számos más részében is értékes információkat közöl a hagyományos orvoslásról.

Vagyis azokról a helyi praxisokról, amelyeknek (leszámítva most mindazokat a helytelen és pusztán kuruzslásnak minősíthető praktikákat, amelyek ellen nap 
mint nap fel kellett venni a harcot) egyik oldalán feltúnik az afrikai gyógyító jellegü, sámánisztikus gyakorlat, tehát az a különleges hagyomány, amely lényegében az európaiak érkezése előtt is már képes volt a lelki, depressziós, pszichoszomatikus jellegủ gondok orvoslását a maga tapasztalati formájában megoldani (ezek újabb kori számbavétele éppen napjainkban folyik). Másrészt viszont Afrika számos pontjáról ismerünk (lásd például többek között Tanzániát) olyan megoldást, amikor a helyi gyógyítókat (healer, herbalist, medicine man) összegyüjtötték, és a modern orvoslási ismeretek birtokában igyekeztek őket arra rávenni, hogy praxisukból miket tartsanak meg, amelyek helyesek, és mit nem, amelyek kártékonyak, bajt okozhatnak.

Különleges és persze a modern világ jelenségkörébe vezet bennünket az afrikai nyersanyagok kitermelésének kérdése. Éppen Biedermann Zsuzsanna az, aki számos korábbi és a korábban említett kötetben közzétett tanulmányában a kérdés szinte valamennyi vetületét számba veszi. Más kérdés, hogy pusztán csak a vasmüvesség kapcsán is volnának sajátosan tradicionális gyökerü információk Afrikából, amelyek a kontinens gazdag ,ipari” múltját is felidézik, és persze érdemes volna feltérképezni, létezik-e még, és hol hagyományos afrikai kovácsmühely (egyébként sok helyütt elkülönült kasztot alkotnak a kovácsok, akik nagy varázslók hírében is állnak).

A mai afrikai gazdaságtörténeti kutatások egyik egyedülálló témaköre kétségkívül az ún. járadékvadászat (leegyszerüsítve: olyan materiális vagy szellemi javak adott esetben törvénytelen úton való megszerzése, amelyeknek bérbeadása munka nélkül is jövedelmet termel). Ennek elemzése esetében (Biedermann Zsuzsanna) számunkra egyébként nem egészen tiszta a felrajzolt kép. Mi a saját szakterületünk felöl, úgy gondoljuk, a klasszikus értelemben felfogott járadékvadászat a bérletbe adott (adható) földbirtok, illetve birtokolt telepek, épületek és eszközök esetében lehetséges. Ebben vélhetöen jelentkeznek olyan motívumok, amelyek a hagyományos Afrika életformáiból következnek (lásd a régi törzsi elitek által birtokolt javak átöröklése), vagyis nem egyszerüen csak klientelizmusról van szó, hanem a felsorolt vagyontárgyak birtoklásából fakadó „visszaélést” a múltból örökölt és ma is élő rokoni és etnikai kapcsolatok segítik elö. Az összes többi lehetőség, az adók, a vámok, sőt még a kereskedelmi korlátozások vagy a koncessziók is, amelyekkel a hatalmat birtoklók folyamatosan visszaél(het)nek, olyan bevételi forrásoknak tűnnek, amelyek jogtalan egyéni (illetve az uralkodó, a jogokat birtokló elitek, csoportok általi) kisajátítása inkább a korrupció, semmint a járadékvadászat fogalmába tartozik. A korábbi fejezetek szigorúan európai szemléletủ fejlesztési elképzeléseinek egyébként gátja lehet többek között a múltból átöröklött birtoklási rend is, amelyre egyébként a szerzők ezúttal maguk is kitérnek. 


\section{AFRIKA GAZDASÁGÁNAK MEGíTÉLÉSE A KULTURÁLIS ANTROPOLÓGIA OLDALÁRÓL}

Végül, de nem utolsósorban azzal kapcsolatban szeretnénk néhány problémát felvetni, illetve sajátos háttérismereteket feltárni, amelyek a gazdag szakirodalomban bármikor jól nyomon követhetők, és persze Szentes Tamás számos elméleti indíttatású szempontja között is rendre szerepelnek. Tehát nyilvánvalóan nem szabad megfeledkeznünk a következőkröl mint (1) az egy före eső GDP mutatószámának elégtelensége, (2) az ideáltipikus (kivonásos) megközelítés korlátai, (3) intézményi jellemzőkre alapított magyarázatok (jogi és politikai intézmények hiánya), (4) intemporális kereskedelem (időleges eladósodás), (5) gyarmatosítással való magyarázatok (különbségek a gyarmatosítás előtt!), (6) függőségek (dependencia-elmélet, nem szimmetrikus függőségi viszony), (7) centrum-periféria elmélet (Szentes ennek kapcsán Arghiri Emmanuel könyvét említi, adatait lásd a bibliográfiában), (8) egyenlötlen csere, (9) külföldi hitelek, technológiák és nemzetközi munkaerö-áramlás és még egy sor elméleti szempont. Most mégis a régiókra, az országcsoportokra (vegyes-telepes gazdaságok, ásványi nyersanyagokra szakosodott országok, mezőgazdasági országok), illetve magukra az országokra, sőt, a nagyobb etnikumokra, és ebben a vonatkozásban is mindenekelőtt a közöttük lévő különbségekre szeretnénk figyelmünket szegezni.

Ugyanis a kulturális, mi több, a gazdasági antropológia oldaláról tekintve a kérdést, úgy látjuk, a lokális különbségek sokkal jelentősebbek, mint hogy az egész kontinensre kiterjedő tanulmányok útján igazán valós eredményekhez juthatnánk. Szentes Tamás a maga általános elméleti szemléletmódjától befolyásolva nem élezi ki az általa is világosan látott különbségeket, még csak az országok szintjén sem. Lásd tehát a következő példákban a mi kiélezettebb figyelemfelhívásunkat:

- Angola a polgárháborútól megszabadulva olajhatalom lett, és mintha ez a vidéki lakosság sorsán is lendített volna, bár a fővárostól távolabb eső területek helyzete nem ismert.

- Ghána nyugodt állapotáról akár magyar utazási könyvből (Pénzes-Kádár, 2017) is értesülhetünk, az ashanti királyság bizonyos keretei ma is fennállnak, de az északi területek népessége ma is nagy elmaradottságban él.

- Zimbabwe, amely a fehér uralom idején prosperáló mezőgazdasági ország volt, egy tehetségtelen afrikai diktátor kezében a kontinens egyik legszerencsétlenebb országává vált.

- Dél-Afrika kivételezett helyzete kezd megkopni.

- Nigéria valószínúleg Afrika legellentmondásosabb országa: (1) Biafra nyomán az olajbevételek az állami oligarchia kezében vannak, (2) az ország talán gazdaságilag legtehetségesebb etnikai csoportja (nemzete), az ibo nép igen feltörekvő, (2) a jorubák esetében még mindig erős a hagyományok jelenléte, ugyanakkor előrehaladott az iszlám befolyás, amely torzítja a gaz- 
dasági gondolkodásmódot, (3) a hauszák esetében a szinte fundamentalista iszlám hatására a gondolkodás középpontjában nem a gazdaság áll, (4) hatalmas városok müködnek felemás urbanizációval stb.

- Mali és Niger küzd a Száhel kiszáradásával, miközben az iszlámhitü nomádok és animista földmủvelők közötti etnikai villongások szinte lehetetlenné teszik a kibontakozást.

- Kitünő példa adódik a Biedermann-Kiss-féle kötetben elemzett Ruanda és Burundi esetében is, hiszen a két országban azonos etnikai (tuszi, hutu, tua), területi (kis országok) és gazdasági adottságok (főleg mezőgazdaság) találhatók, a két ország helyzete jelenleg mégis merőben más.

De hogyha az országszintü különbségek mellett az etnikai csoportok viszonylatában is példákkal szeretnénk alátámasztani állításunkat, íme:

- A haják (haya) egy pár százezres bantu nyelvet beszélő népcsoport Kenyában, sok kisebb hagyományos törzs (törzsi királyság) sejlik a múltjukban, szerencsés véletlen folytán már a 19. század végén dohányt kezdtek termeszteni, amelyet más mezőgazdasági termelvényekkel kiegészítve, jól prosperáló gazdaságot teremtették, és jóval tehetősebbek, mint a területük körzetében, igen szegény körülmények között élő szomszédaik.

- Sárkány Mihálynak az elmúlt évtizedekben az ugyancsak kenyai, bár sokmilliós kikujuk körében végzett vizsgálataiból kiderül, hogy ugyanez a helyzet alakult ki e nép körében a (vélhetően őshonos) kávéültetvények folytán.

- A Kongó folyó torkolatánál él egy viszonylag kis bantu csoport, a nevezetes vagenya halászok, akik különleges folyó feletti építményekkel és varsákkal nagy mennyiségủ halat voltak képesek lehalászni, és megélhetésüket, sőt, bizonyos meggazdagodásukat ennek a technikának köszönhették (a Torday Emil idejében, száz évvel ezelőtt már ismert tevékenység ma is létezik) (Torday-Joyce, 1911).

- Ugyancsak Torday Emil egykori nevezetes terepmunka helyszínét idézi a közép-kongói (ba)kubák törzsi körülmények között is igen fejlettnek számító gazdasága, leszámítva most világhírü királyi müvészetüket (lásd a régi uralkodókat ábrázoló, fából készült csodálatos és ndop-nak nevezett mellszobrokat), ma már a világ minden tájára eljut igen keresett kézmüipari termékük, a sajátos mintázatú rafiaszőnyeg, míg Mary Douglas (az ötvenes évekből) leírja, hogy a Kasai-folyó túlpartján élö lele nép mindebből semmit sem tud a magáénak, gazdasági tevékenységük jóval szegényesebb (Douglass, 1963).

- És a már említett nigériai ibók (jóval több mint 30 milliós nemzet!) büszkék arra, hogy a területükön sosem jött létre olyan abszolutisztikus eszközöket alkalmazó törzsi királyság, mint például a jorubák körében, afféle egymás melletti faluk közösségében éltek és élnek, gazdasági prosperálásukat saját maguk is ezzel a demokratikus hagyománnyal igyekeznek értelmezni. 


\section{TANULSÁGOK}

Vagyis az elmondottakat összegezve (a példák számát persze százával lehetne még szaporítani!), a természeti adottságok mellett olyan mentalitásbeli különbségekkel is kell számolnunk, amelyek arra intenek bennünket, hogy a kontinens gazdaságát nemcsak a világgazdaság diktálta globális megközelítéssel, hanem alulról vagy belülről, a kisebbség (etnikai csoportok, népek, országok) irányából is meg kellene vizsgálni.

Úgy tűnik, amikor a kontinens gazdaságát vizsgáljuk, ezt a redukciót ugyancsak el kell végeznünk: le kell szállnunk az afrikai népek és országok szintjére, hogy ne csak nagy vonalakban lássuk a szubszaharai népek ökonómiáját, hanem mélyebben is megismerjük a tényeket, értsük a problémákat, meglássuk az öszszefüggéseket. Mégpedig a nemzetközi vagy világgazdaság-elemzési technikák és elméleti megfontolások felhasználása mellett a gazdasági antropológia segítségével is. Még akkor is, ha persze ennek a tudománynak a lényege elsősorban nem a számszerüsítés (bár az említett és a hagyományos piacok életét bemutató Bohannan-féle kötetben [Bohannan-Dalton, 1962] például nagy számban kapunk számszerü adatokat is).

\section{IRODALOM}

Biedermann Zs. - Kiss J. (szerk.) (2017): A szubszaharai Afrika gazdasága a XXI. században. (Nemzetközi gazdaság sorozat) Budapest: Akadémiai Kiadó

Bocoum, H. (ed.) (2004): The Origins of Iron Metallurgy in Africa - New Lights on Its Antiquity. Paris: UNESCO, https://unesdoc.unesco.org/ark:/48223/pf0000133843

Bohannan, P. - Dalton, G. (eds.) (1962): Markets in Africa. Evanston: Northwestern University Press

Douglas, M. (1963): The Lele of the Kasai. London: Oxford University Press

Ecsedy Cs. (1965): Bohannan, P. and Dalton, G. (eds.): Markets in Africa. Ethnographia, 76, 2, 289-291. (ism./review)

Emmanuel, A. (1972): Unequal Exchange. A Study of Imperialism of Trade. New York: Monthly Review Press

Hoppál M. (szerk.) (2016a): Sámánok régen és ma. (Szenzár Könyvek) Budapest: Helikon Kiadó

Hoppál M. (2016b): Jelek és sámánok a sziklarajzokon. Budapest: Gondolat Kiadó

La Fontaine, J. - Richards, A. I. (1959): The Haya. In: Richards, A. I. (ed.): East African Chiefs. London: Faber and Faber, 174-194.

Lewis, I. M. (1989): South of North: Shamanism in Africa. A Neglected Theme. Paideuma, 35, 181-188. https://www.jstor.org/stable/40733031?seq=1/subjects

Pénzes T. - Kádár I. (2017): Ghána ölelésében. Fényképes útinapló. Érd: Mundus Novus Könyvek Pusztai Gabriella (2016): Senki sem élhet nemesebben. Magyar orvosok Fekete-Afrikában. Kunszentmárton: Helytörténeti Múzeum

Szilasi I. (2010): Vagenya halászok Kongóban régen és ma. Spektrum: A világ te vagy, szeptember-október, 32-47. 
Szilasi I. (2014a): A kuba királyszobrok változása, Ethnographia, 125, 4, 521-543.

Szilasi I. (2014b): A kuba rafia szövetek változása. In: B. Wallner E. (szerk.): Afrikakutatás Magyarországon-elsö kötet. A 70 éves Biernaczky Szilárd Afrika-barátság könyve. Érd: Mundus Novus Könyvek, 245-260.

Sárkány M. (1983): A törzsi társadalmak gazdasága. Magyar Filozófiai Szemle, 5, 738-748.

Sárkány M. (2001): Kávé és földtulajdon a kikujuknál. In: Hála J. - Szarvas Zs. - Szilágyi M. (szerk.): Számadó. Tanulmányok Paládi-Kovács Attila tiszteletére. Budapest: MTA Néprajzi Kutatóintézet, 171-177.

Sárkány M. (2015): Hogyan termelnek és nem termelnek kávét kikuju kisbirtokosok? In: Jakab A. Zs. - Kinda I. (szerk.): Aranykapu: Tanulmányok Pozsony Ferenc tiszteletére. Kolozsvár: Kriza János Néprajzi Társaság-Szentendrei Szabadtéri Néprajzi Múzeum-Székely Nemzeti Múzeum, 607-617. https://bit.ly/2QyUvXf

Torday E. - Joyce, T. A. (1911): Notes ethnographiques sur les peuples communément appelés Bakuba, ainsi que sur les peuplades apparentées: Les Bushongo. (Musée du Congo Belge. Annales D. Ethnographie, Anthropologie, Ser. 3. Vol. 2/1.) Bruxelles: Ministère des Colonies, https://gallica.bnf.fr/ark:/12148/bpt6k6475837f.texteImage 